\title{
The Impact of Applying the Electronic Cheque Clearing System on Employees' Satisfaction in Accounting Departments' of Jordanian Islamic Banks
}

\author{
Adel M. Qatawneh ${ }^{1}$, Fairouz M. Aldhmour ${ }^{2}$ \& Lara T. Aldmour ${ }^{3}$ \\ ${ }^{1}$ Accounting Department, Al-Zaytoonah University, Jordan \\ ${ }^{2}$ Management Information System Department, Mutah University, Jordan \\ ${ }^{3}$ Business Administration Department, Mutah University, Jordan \\ Correspondence: Adel M. Qatawneh, Accounting Department, Al-Zaytoonah University, Jordan. E-mail: \\ qatawneh@yahoo.com
}

Received: December 14, 2015

Accepted: December 29, $2015 \quad$ Online Published: January 25, 2016

doi: 10.5539/ibr.v9n2p137

URL: http://dx.doi.org/10.5539/ibr.v9n2p137

\begin{abstract}
This study aims to investigate the impact of applying the electronic cheque clearing system on employees' satisfaction in Accounting Departments' of Jordanian Islamic banks. The population of this study was the employees who work at the Accounting Departments. A random sample of (150) employees who work in Accounting departments, particularly clearing directory in the Islamic Banks in Jordan were chosen to be the sample of the study. One hundred and fifty questionnaires were distributed to the employees who work in clearing directory and those who worked in this directory in the Islamic Banks in Jordan. The results indicate that there is a weak impact of the independent variable the applying ECC system (Reliability, Responsiveness, Tangibility and Privacy) on the dependent variable (Employees' Satisfaction) in Jordanian Islamic banks. Against expectation, the results show that only Tangibility has a positive and significant relationship with 'Employees' Satisfaction. The researchers recommended that employees' satisfaction in bank sector may affect customers' satisfaction positively or negatively because most of employees in this sector deal with customers face to face.
\end{abstract}

Keywords: electronic cheque clearing system; employees' satisfaction; Jordanian Islamic banks; accounting department; accounting information systems

\section{Introduction}

The financial electronic Banking services industry represents the most important results of the development of the contemporary scientific and technological. It is also one of the features of the economic boom. The technological revolution of contemporary and the accompanying spread in the use of the Internet and information technology for all business and rapid rates in the world, banking sector of the former sectors in this area and that have adopted many electronic uses to improve their performance and gain an edge over the competitive strategy (Maxwell, 2011). The Central Bank of Jordan has taken a decision to follow the movement of money or cheques and trading between banks using information and communication technologies, including so-called electronic clearing system. The main mechanism of action with new system of filming "Clear" cheque paperwork which was scanned upon receipt by the employee of the receiving bank to a clearing machine in the Central Bank for registration electronically and forward it to the bank for rich authentication with the motive of financial exchange during the same day of deposit (Lee, 2009). Traditional cheque clearing process is time consuming and lengthy it affects value of transaction of settlement (Alabar \& Agema, 2014). It is a time consuming process and also require a lot of human effort and time (Hrishikesh et al., 2014).

\section{Theoretical Background and Hypotheses}

"Electronic banking is the use of information and communication technology by banks to provide services and manage customer relationship more quickly and most satisfactory", a bank serves as an intermediary between savers or depositors and borrowers. Globalization and financial liberalization constitute major changes that have significantly affected banks and this has resulted in competition between banks forcing individual banks to find new market to expand. One major tool employed is the use of information technology (Olanipekun et al., 2013). 
So banks in the whole world should transform into a electronic transactions system. This system allowed them to speed their work, enhanced their security, privacy and reduced cost and time of transactions.

The researchers could conclude that electronic banking is application of advance information technology in banks to introduce their services to their customers more quickly (Olanipekun et al., 2013; Welch, 1999; Yasuharu, 2003). It also made an implication of information technology which revolutionized their functions and caused dramatic change in their industry. In this research the researcher will focus on side that related to electronic banking that concern with electronic cheque clearing system.

\section{Electronic Cheque Clearing (ECC)}

Electronic clearing is defined as information, data, images and checks symbols) by electronic means through electronic clearing section at the (CBJ) and at a specific time determination of net balances resulting from this process (Association of Banks in Jordan, 2009). The aim of checks electronic clearing is to stop dealing with paper checks for clearing purposes at the depositing stage in banks, and to collect checks in the same day; The Central Bank of Jordan (CBJ) moved a step in enhancing dependence on information through check electronic clearing system (AL-Refai1 \& Nawafleh (2014). The deployment reflects the banking industry's commitment to the digital cheque clearing process (Central Bank of Jordan, 2013).

\section{Cheque Clearing Process}

Traditional cheque clearing process is time consuming and lengthy it affects value of transaction of settlement (Alabar \& Agema, 2014). It is a time consuming process and also require a lot of human effort and time (Hrishikesh et al., 2014).

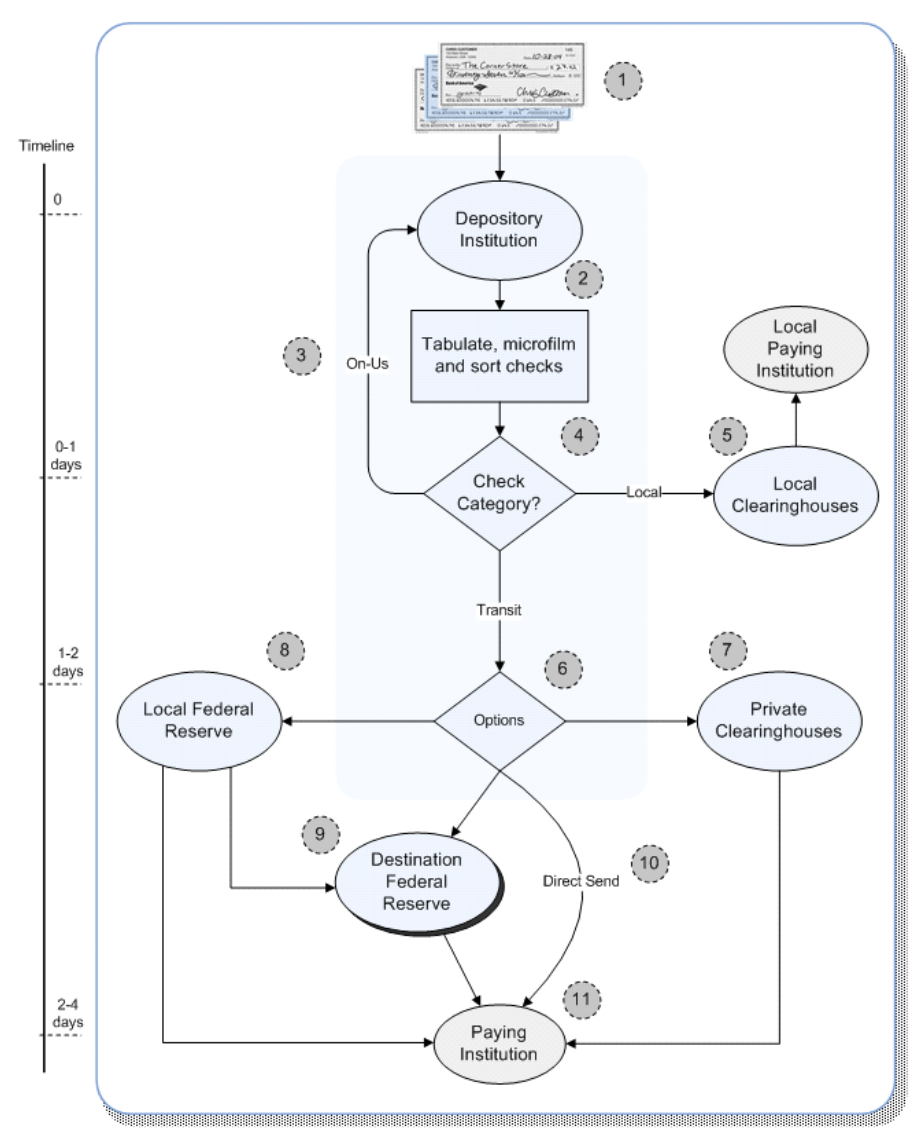

Figure 1. Traditional cheque processing.

Resource: (Jeremy and Euston, 2005).

\section{Electronic Cheque Clearing Systems (ECC)}

An electronic cheque clearing system (ECCS) is defined as the process of inter-bank cheque settlement by using 
both cheque electronic records and scanned copy of the cheque (Pasupathinathan et al., 2005). Once the teller in the bank of first deposit (BFD) receives the cheque item, the scanned copy is sent to the paying bank through the central bank to be technically and financially cleared through high speed secure connection lines. The reply for that action to pay or reject the cheque is generated from the paying bank to the central bank and then sent to (BFD) (Jresat, 2007). On the contrary to the traditional cheque clearing process, this occurs at the central bank clearing center with the physical attendance of all banks' representatives (Yahya et al., 2011).

The center of the cheques clearing process is the clearing house, central bank, monetary agency or Federal Reserve. The roles of all these governmental institutions is to verify the cheque clearing process and enforce financial procedures, regulations and laws, as well as to monitor and follow up their implementation (CBJ Website, 2009).

When a customer deposits a cheque at a bank, the sending bank captures both the front and the back of the cheque into cheque images as well as prepares the data related to the cheque in order to send them online to the Electronic Clearing House (ECH). The ECH will sort the cheque images and data before sending them to the appropriate paying bank for verifications and approval of payment. If payment for the cheque is refused, the paying bank will inform the ECH online of the return status of the cheque, the ECH will inform the sending bank accordingly. The sending bank will then return the physical cheque attached with cheque return advice to the customer.

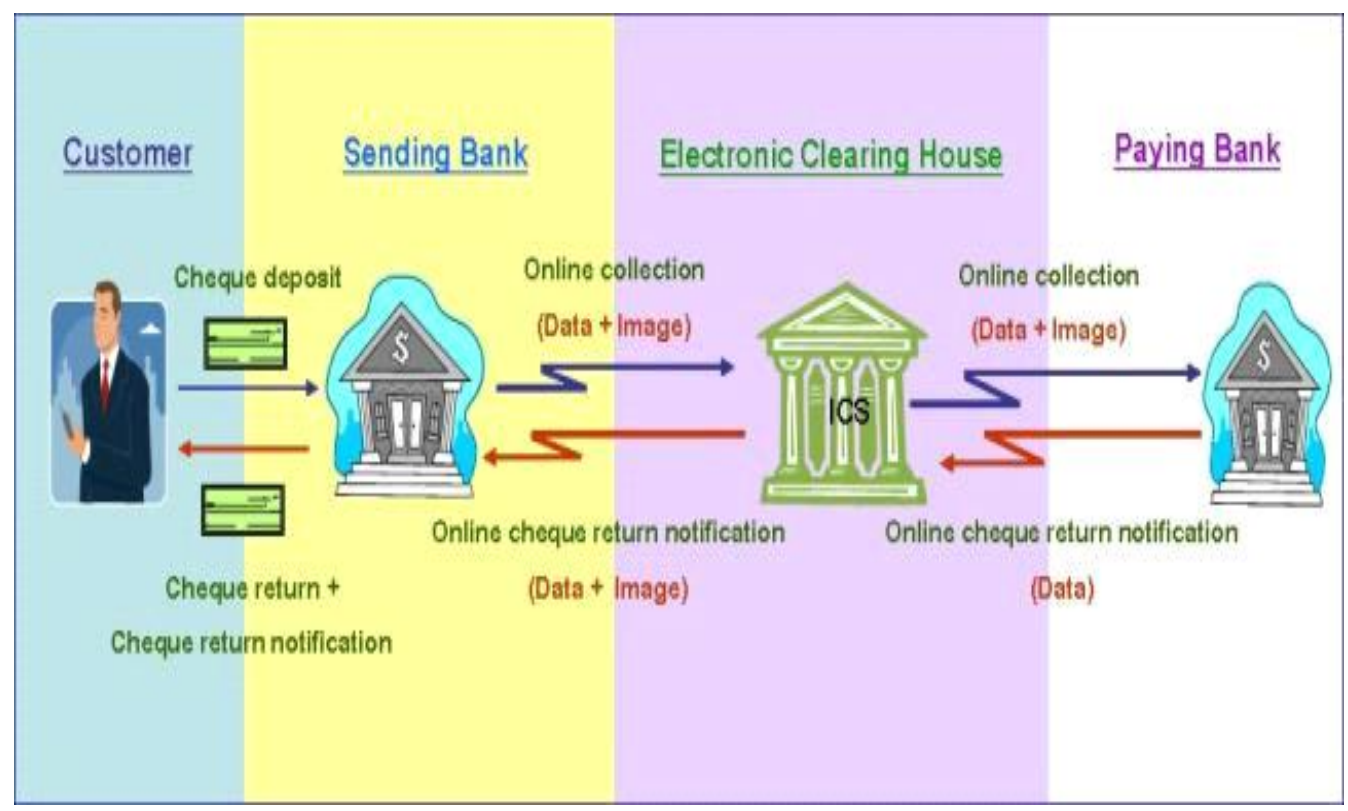

Figure 2. Cheque collection process in the ECC

Source: Bank Thailand, www.bot.or.

Clacher (2006), Jersat (2007), Somkid (2012) and Bank Thailand posed the following benefits for using ECC process:

- This system is cleared cheque using an image instead of physical paper as before.

- This system will also allow for the storage of electronic data and images.

- This system can be used as legal evidence without physical paper.

- This system also stimulates the economic growth and reduces the labor costs and papers.

- Imaged cheques are easy to process, transfer and retrieve.

\section{Variable of the Study}

\subsection{Reliability of ECC}

"Reliability refers to the ability to execute the promised service in an accurate and reliable way" (Yang, 2002). According to Parasuraman et al. (1988) "reliability is one of the most important Dimensions of quality of service". On the other hand, some studies found that reliability represents the most important dimensions of 
electronic service quality (Sukasame, 2010). Santhiyavalli (2011) pointed that reliability refers to the trust in banks' ability of performing service in a proper way, such as acting according to promises and declarations. A reliable service means the banker is able to provide internet connection that is working at desired level throughout the day without significant failures; banker should not misuse the cardholder information and there should be frequent update of new technologies.

\subsection{Tangibility of ECC}

"Tangibility included Facilities material used in the work from the outside appearance of the bank and prepares the inside of the devices and methods used in the performance of the service. They include the physical elements of the service (the seats, lights, chairs, equipment)" (Berry et al., 1985). While Santhiyavalli (2011) described tangibility as the things which are physically observed by the customers in the bank branch including large ATM network, personnel, physical facilities, materials and appearance. Able and skilled personnel, the quality of banking products and services, brochures and cards may represent tangibles. These qualities provide concrete cues for customers to evaluate the capability of the service provider. The following equipment and software are the most necessary for applying ECC at banks; Cheque Scanner, Desktop PCs, Software, Electronic Cheque Clearing Web.

\subsection{The Privacy}

Belanger, Hiller and Smith (2002) and Cavoukian and Dixon (2013) looked at Privacy as personal manage and control over their personal information with respect to its collection, use and disclosure. Hua (2009) pointed that to understand the user's adoption of online banking, security and privacy concerns should not be ignored because those are the most important concerns for trust building which has been pointed out as the top two factors influencing user' adoption. Privacy policy has been proven to be an important factor influencing people's behavioral intention of acceptance of online banking while a specific privacy policy may have more impact on the adoption of online banking. Customer and Bank represent, warrant and mutually agree that all confidential information concerning the other party or parties that comes into its possession in connection with the Service will be maintained in strictest confidence and shall not be used or divulged to any other party except as may be necessary or advisable for the due performance of the Service or as required by applicable law (UMPQUA Bank).

The theory of planned behavior can be considered as "a rational-cognitive model of decision-making, in that individual are assumed to weigh up attitudes, norms, and control in forming intentions and actions. Two important affective variables that are likely to be particularly relevant in relation to online privacy protection are perceived risk and perceived trust" (Lee, 2009; Paine et al., 2006). Perceiving online activities as risky is associated with reduced service use (Lee, 2009) and with increased privacy protection (Alter \& Oppenheimer, 2009; Paine et al., 2006; Youn \& Hall, 2008). Trust underpins any positive relationship; it is the willingness of one party to act or speak in such a manner that they are made more vulnerable to the other party (Cozby, 1973). One way to create trust is through self disclosure (Rotter, 1980): By disclosing personal or private information, rapport and intimacy in interpersonal relationships is increased and individuals are perceived as more trustworthy themselves (Henderson \& Gilding, 2004).

The theory of planned behavior has demonstrated efficacy as a conceptual framework for examining the antecedents of behaviors and effecting behavior change. Themodel has been used to examine a range of health behaviors (Duncan, Forbes-McKay, \& Henderson, 2012; Karimi-Shahanjarini et al., 2012; Louis et al., 2007), socially-minded behaviors such as energy conservation (Nolan et al., 2008) and charitable intentions to donate (Knowles et al., 2012), and hundreds of other behaviors (Armitage \& Conner, 2001). In recent years, researchers have examined the utility ofthe TPB in relation to online behaviors, such as online musicpiracy (d'Astous et al., 2005), online stock trading (Lee, 2009), and online privacy protection (Yao \& Linz, 2008; Yousafzai et al., 2010). In the domain of online privacy protection, research has generally supported the role of attitudes and intentions as predictors of behavior, with less support for the role of norms (Yousafzai et al., 2010). However, this research has also considered the role of affective variables, such as fear of crime (Yao \& Linz, 2008) or trust (Yousafzai et al., 2010), illustrating those additional factors may be important in this context.

\subsection{Responsive}

"Responsive refers to willingness to assist the end users and provide punctual service" (Lee, 2009). Adding, Al-Tamimi (2007) Defined it as "the desire to help customers and speed the completion of service". Both of Lee, (2009) amd Al-Tamimi (2007) focused in their definition on the assisting of the customer and introducing him the required service and this meaning that the researcher will employee in this study. 
Bowen et al. (1999) concluded that when front-line employees feel they have been treated fairly, they are more likely to treat the customers fairly. In a subsequent study of the relationship between bank employees and customers. Bowen et al., (2000) found that employee morale is strongly related to customer satisfaction; that is, when bank customers perceive front-line employees are happy with their work, bank customers are more likely to be satisfied with the service they receive.

Some researcher pointed that this job is related to the managers responsibilities like Lymperopoulos and Chaniotakis (2004) who argued that banks normally assign their managers responsibility for the promotion of the use of electronic channels to customers. Their input as delivery staff is important. It is also the manager's responsibility to ensure that branch staff is professional, well-trained and knowledgeable about the range of services provided by the bank (Moutinho, 1997). Also Moutinho and Phillips (2002) found that managers considered efficiency and enhancement of customer service to be two perceived advantages of Internet banking. Similarly, Aladwani (2001) highlighted faster, easier, and more reliable service for customers, and improvement of the bank's competitive position to be the most important drivers of online banking among bank and information technology managers. Howcroft et al. (2002) found that the most important factors encouraging consumers to use online banking are lower fees followed by reducing paper work and human error. Banks provide customers convenient, inexpensive access to the bank 24 hours a day and seven days a week (Moutinho et al., 1997).

Nancy et al. (2001) viewed the same situation differently and argued that customers like to interact with humans rather than machines. They found more possibilities for asking questions and believe that bank clerks are less prone to errors. It is thus essential that any face-to-face transactions are carried out efficiently and courteously. This increases the possibility of selling the customer another service that they need and also promotes a good image and enhances customer loyalty (Moutinho et al., 1997).

\subsection{Employees' Satisfaction}

Job satisfaction is defined as all the feelings that an individual has about his/her job (Panchanatham, 2011). The satisfaction of employee is analyzed actually by the output that the individual produces and it is related to office environment. At corporate level, employee satisfaction is affected by many factors such as lighting, furniture, noise, temperature and other arrangement. It is also dependent on the physical environment and its affect on health and employees satisfaction (Bolton, 1991). The satisfaction of office workers does not seem to be an exception. The organizational structure and culture, the management style, the nature and complexity of the work done and the facilities provided play a major role in determining the amount and quality of the output from our labor. Personal characteristics, competences and motivation play an important part too. Both scholars and facility services providers are interested for a long time in the relationship between facilities and employee satisfaction (Chigot, 2005; Edwards \& Torcellini, 2002).

Employee satisfaction is an important success factor for all organizations. Employee satisfactions have been recognized to have a major impact on many economic and social phenomena, e.g. economic growth and higher standard of living. Companies must continuously employee satisfaction in order to stay profitable Aarti et al. (2013). Job satisfaction represents a combination of positive or negative feelings that workers have towards their work. Meanwhile, when a worker employed in a business organization, brings with it the needs, desires and experiences which determinates expectations that he has dismissed. Job satisfaction represents the extent to which expectations are and match the real awards. Job satisfaction is closely linked to that individual's behavior in the work place (Aziri, 2011).

Aarti et al. (2013) concluded that some factors causing dissatisfaction regarding job, some are neither causing dissatisfaction nor contributing much towards job satisfaction. Factors like working environment of the employees, performance appraisal techniques, relationship with other employees and grievance handling and safety provisions are contributing towards job satisfaction as dissatisfaction caused by these factors are almost negligible.

\section{Research Model and Problem}

The independent variables (Responsiveness, Privacy, Reliability and Tangibility) and the dependant variable (Employees' Satisfaction).

\subsection{Operational Definitions}

The researcher developed the following operational definitions that meet what the researcher intended to investigate to be the base on which the questionnaire questions will build on.

Tangibility: It is the appearance of physical facilities, equipment, personnel and communication materials that 
required for applying the ECC.

Reliability: It is the finishing cheque clearing at specific time, interesting in customer problems that related to ECC process, doing this process accurately and sending necessary ECC reports to the customers about his ECC operations.

Responsiveness: It is the willingness of employees in the Islamic banks to help customer and provide him prompt services.

Privacy: Customers' assurance that their personal information that related to their dealing with the ECC is well-protected and only they can manage and control them.

Employees' satisfaction: Employees' positive emotional feeling toward their work which lead to their acceptance to this work, continue in their work and doing it effectively.

\subsection{The Statement of Problem}

"Traditional cheque clearing process is time consuming and lengthy it affects value of transaction of settlement" (Alabar \& Agema, 2014). "It is a time consuming process and also require a lot of human effort and time" (Hrishikesh et al., 2014). Electronic clearing is one of the most important and the greatest achievements of the central bank, especially that it is consistent with the vision of the leadership of Jordan toward technical progress and the electronic switch that serves the national project leading goal electronic government, which helps in the management of money larger whether companies or even individuals, which will be reflected in benefiting of the citizen and the national economy.

It will also provide the best possibilities for the banking sector and electronic archiving system of cheques and information to keep them as characterized by efficiency, accuracy, and in line with the Electronic Transactions Act. In addition to being also in line with technical developments in the world and allows immediate control cheques, Which encourages banks to proceed with the adoption of electronic clearing system to achieve its goals and ending the high quality and competition in banking services (Central Bank of Jordan, (CBJ)). This study aims to investigate the impact of the applying e-clearing services in customers' satisfaction in Jordanian Islamic banks. The researcher tries to answer the following central question:

What is the impact of the applying the electronic cheque clearing system (ECC) in employees' satisfaction in Jordanian Islamic banks?

To answer the aim question, the following sub questions were proposed:

1) What is the respondents' perceptions level toward the ECC system?

2) To what extent do Islamic banks in the south of the Jordan apply the ECC system?

\section{The Importance of the Study}

The importance of this research derives from the following:

- There is a lack in studies that focus on electronic clearing in terms of its impact in employees' satisfaction in Jordanian Islamic banks. As a result, this research serves as being a good starting point for future research projects and studies. Moreover, this research study can also be used as a reference and a help in providing other researchers beneficial information and a clearer direction when embarking on future research projects relating to clearing system in Jordan.

- The importance of the study addressed the dimensions of quality of service both types of traditional and electronic.

- To gain a competitive advantage and also function in attracting new customers. The finding and recommendation of this research can assist local \& foreign banks in developing appropriate banks strategies that can help them to apply the electronic clearing system effectively and efficiently.

\section{Aims and Objectives}

The aim of this research is to identify the impact of the applying e-clearing in employees' satisfaction in Jordanian Islamic banks. To achieve this aim, the following objectives have emerged:

1) Measure the extent of the applying of the ECC in the context.

2) Investigate the impact of the applying of ECC in employee satisfaction.

3) Make some recommendations that will help to realize the importance of the applying of ECC for customers and employees in the context. 


\section{Study Design and Methodology}

\subsection{Purpose of the Study}

Sekaran (2003) states that the nature of studies may either be exploratory, descriptive, or it may be conducted to test hypotheses. According to the research purpose this research is a hypothesis testing study. "Studies that engage in hypotheses testing usually explain the nature of certain relationships, or establish the differences among groups or the independence of two or more factors in a situation" (Sekaran, 2003). This study is conducted to test hypothesis to generate some findings that may be generalized to all banks in Jordan in order to help them to enhance their electronic services, precisely their ECC services. It also aims to introduce some recommendations for future researches (Alaumayrien, 2013).

\subsection{Design of the Study}

Research design includes both a theoretical and methodological approach. The theoretical approach can be either inductive or deductive, and methodological approach is qualitative or quantitative (Zikmund, 2003). Therefore, the deductive approach is followed in this study to reach its aim. It introduces a theoretical framework from which the study hypotheses are built then tested to reach the findings that may be generalized later. The methodological approach that used in this study is a quantitative approach Likert five- point scale questionnaire is used to collect data that are represented numerically from one to five (Alaumayrien, 2013).

Therefore, this research is applied research in which the researchers seek to reach some findings that may be applied to enhance ECC services in the Jordanian banks.

\subsection{Population and Sampling}

Sekaran (2003) defines a research population as the entire group of people, events, or things of interest that the researcher wishes to investigate. The population of this study was the employees who work at the Islamic Banks in Jordan. A random sample of (150) employees who work in accounting departments particualary clearing directory in the Islamic Banks in Jordan were chosen to be the sample of the study.

\subsection{Data Collection}

Likert five-point scale questionnaire was developed based on literature and the hypotheses to collect the required data. Secondary data was collected from records, documents of the Islamic Banks, CBJ and relevant researches. One hundred and fifty questionnaires were distributed to the employees who work in accounting department and those who worked in this directory in the Islamic Banks in Jordan.

\subsection{Questionnaire Design}

In order to develop the questionnaire for this study, it was necessary to read previous studies to see if a suitable tool already existed, which had previously been tested in a similar context to the current study. The researchers conducted a review of other literature related to questionnaire design. This helped the researchers to construct a suitable questionnaire of thirty-two item. The main purpose of the questionnaire that is used in this study is to collect particular kinds of data to yield reliable evidence related to its objectives. Questions are carefully constructed and be relevant to the hypotheses of the study. The Questionnaire has been divided into three sections. Section one contains the demographic data and section two contains twenty statement which is divided into four sections each one has some statements relates to one of the independent variables and the third section contains twelve statements relates to the dependent variable. Employees were asked to mark a tick in the appropriate box in sections 1-2.The questions have been designed to invite responses along a five-point scale (strongly agree, agree, neutral, disagree, and strongly disagree) (Alaumayrien, 2013). The reason why the researcher used a five-point scale is that it gives the respondents more freedom of choice without any pressure. Besides, it is commonly used in educational and social fields (Robson, 1996). Six questionnaires were excluded because they were incomplete.

\section{Instrument Reliability and Validity}

\subsection{Reliability}

According to Sekaran and Bougie (2010) the most popular test of inter-item consistency reliability is Cronbach's alpha coefficient. Hence, Cronbach's alpha test is employed in this study to measure internal consistency of the instrument. Twenty participants were selected from the employees of Islamic Banks in the south of Jordan who would be the potential participants for the main study to conduct the Pilot Test. As shown in Table 1 all the result for alpha coefficient of the items of each variable alone and alpha's value of the whole instrument suggested that the items have relatively high internal consistency. They are greater than the guideline of .70 which means that the scale can be applied to the analysis with acceptable reliability (Sekran, 2006). 
Table 1. Reliability statistics

\begin{tabular}{cc}
\hline Variables & Cronbach's Alpha \\
\hline Responsiveness & .843 \\
Privacy & .710 \\
Reliability & .740 \\
Tangibility's & .732 \\
Employees' Satisfaction & .815 \\
For all variable items & .818 \\
\hline
\end{tabular}

\subsection{Validity}

Content and face validity ensure that the measure consists of an adequate and representative set of items that tap a particular concept. Differently, it involves a systematic assessment of the scale's ability to measure what is supposed to measure. Hence, content validity entails consulting a small sample of typical respondents and/or panel of expert to pass judgment on the suitability of the items selected to measure a construct (Samouel \& Page, 2007; Sekaran \& Bougie, 2010). Based on this, a draft of the instrument of this study was distributed to the members of faculty of business administrative at Mutah University in order to get feedback concerning the suitability, content, layout and adequacy of the items that are designed to measure the constructs under investigation.

Additionally, some Ph.D. candidates who are familiar with the context of the study were equally contacted to check the clarity of the study instrument. To this end, a number of questions were re-worded/re-phrased in order to measure the constructs appropriately and also to be understandable to the potential respondents. It was also observed that some items look the same and therefore, some items were removed. After taking into consideration of the observation by the experts, then the researcher came up an improved version of the instrument which was ultimately administered for the pilot test (Maiyaki, 2011).

Discriminant validity of all variables (Responsiveness, Privacy, Reliability, Tangibilitys and Employees' Satisfaction) were determined and found within range proving no collinearity. The cutoff value for discriminant validity is: < 0.85 (Harrington, 2009; Garson, 2009); < 0.60 (Leech et al., 2005); and Dimovski (1994) mention cut-off value for Pairwise Correlation is $<0.55$ significant at $<0.05$. The results of Pairwise Correlation of the variables of this study indicate their values are significant at $\mathrm{p}<0.01$ or at $<.05$.

Moreover, it is found that all correlations are positive providing additional proof for construct validity (Vekatraman, 1989). Hence, discriminant validity criteria are satisfied by these variables. This indicates that each variable is distinctly different from the other variables (Naveed, 2013).

\section{Data Analysis and Research Finding and Discussion}

\subsection{Descriptive Analysis of the Sample}

This part of the study is about the frequencies and percentage of the sample of the study according to its demographic characteristics (gender, age, education level, annual income and experiences).

Table 2. Frequencies and percentages of respondents

\begin{tabular}{cccc}
\hline Percent & Frequencies & & Measure \\
\hline 68.1 & 98 & Male & Gender \\
31.9 & 45 & Female & Age \\
42.4 & 61 & 30 or less & \\
34.7 & 50 & $31-40$ & \\
11.1 & 15 & $41-50$ & Education level \\
11.8 & 17 & 51 or more & \\
6.9 & 10 & Diploma or less & \\
68.8 & 99 & Bachelor & Annual Income \\
24.3 & 35 & High Education & \\
51.4 & 74 & 10000 or less & \\
33.3 & 48 & 10001 to 20000 & \\
10.4 & 15 & 20001 to 30000 & \\
4.2 & 6 & 30000 or more & \\
\hline
\end{tabular}




\begin{tabular}{lccc}
\hline 11.8 & 17 & less than one year & Experience \\
25.0 & 36 & Two to five & \\
29.9 & 43 & Six to ten & \\
33.3 & 48 & more than 10 & Total \\
$100 \%$ & 144 & & \\
\hline
\end{tabular}

\subsection{Data Analysis \& Results}

\subsubsection{Test of the Assumptions of Regression Analysis}

Each of the research Hypotheses was tested through multiple regression analysis to test their impact on the dependant variable. Multiple regression analysis is a statistical method which is used to explore the relationship between the predictor variables (independent) and response or dependent variable (Johnson \& Wichern, 2006). This technique helps to understand the amount of variance in the dependent variable explained by a set of independent variables and both types of variables are measured on continuous scale (Sekaran, 2003). But before using multiple regression analysis, some tests were done to verify that the data have met the regression assumptions or the results may be misleading. In particular, the researchers will consider the following assumptions: Firstly, the researcher tested collinearity by estimating the values of the Variance Inflation Factory (VIF) and the Tolerance for each one of the independent variables to ensure that predictors (independent variables) are not highly correlated to avoid problems in estimating the regression coefficients that highly correlating can cause. Secondly, the researcher ensured that data are normally distributed by estimating the Coefficient of Skewness. As shown in Table 3 the values of VIF for each one of the independent variables are less than (10) and the values of Tolerance are higher than (0.05), so the result of the two tests indicate that there is not high correlation between the independent variables. The table also shows that Skewness values are less than (1) which means the data are normally distributed (Alameryien, 2013).

Table 3. Collinearity, tolerance and coefficient of skewness

\begin{tabular}{cccc}
\hline Skewness & Tolerance & VIF & ID variables \\
\hline-.878 & 1.521 & .658 & Reliability \\
-.009 & 1.031 & .970 & Responsiveness \\
-.411 & 1.056 & .947 & Tangibility \\
-1.032 & 1.522 & .657 & Privacy \\
\hline
\end{tabular}

\subsubsection{The Results of Testing the Hypotheses}

H01: There is no statistical significant impact of applying ECC system in employees' satisfaction in Jordanian Islamic banks.

Table 4. Multiple regression results for the impact of applying ECC system in employees' satisfaction in Jordanian Islamic banks

\begin{tabular}{cccccccc}
\hline IV & Model & df & R-Square & Sum of squires & Mean squire & F & Sig. \\
\hline \multirow{2}{*}{ ECC } & Regression & 4 & .075 & 2.362 & .591 & 2.833 & $.027 *$ \\
& Residual & & & 29.007 & .209 & & \\
\hline
\end{tabular}

Note. *Significant level at $(\alpha \leq 0.05)$.

As shown in Table 4, Multiple Linear Regression revealed that $\mathrm{F}$ value was (2.833) and its probability (.027), so F-test is statistically significant at $(\alpha \leq 0.05)$. R Square was (.075) which means that the whole model predicts $7.5 \%$ of variance in the dependant variable (Employees' satisfaction) and $92.5 \%$ of variance in the dependant variable (Employees' satisfaction) was explained by other factors. This result also indicates that the whole model is statistically significant. 
Table 5. Multiple regression results for the impact of applying ECC system in employees' satisfaction in Jordanian Islamic banks

\begin{tabular}{ccccccc}
\hline Sig & $\mathrm{t}$ & Beta & Std.E & $\beta$ & Independent Variables \\
\hline .299 & 1.042 & .086 & .087 & .091 & Reliability \\
.779 & .281 & .028 & .084 & .024 & Responsiveness \\
$.019^{*}$ & 2.368 & .198 & .090 & .213 & Tangibility \\
.304 & 1.031 & .104 & .092 & .095 & Privacy \\
\hline
\end{tabular}

Note. *Significant level at $(\alpha \leq 0.05)$.

The result of Table 5 revealed that $\mathbf{t}$ values for the independent variables (Reliability, Responsiveness and Privacy) are (1.042, .281 and 1.031 respectively) and all of them are not statistically significant at $(\alpha \leq 0.05)$ which means that all these variable don't contribute to the model and that these variables have no impact on the dependant variable (Employees' satisfaction). But the independent variable (Tangible) values $(\mathrm{t}=2.368$ and its significant (.019)) indicates that it contributes to the whole model and have impact on the dependant variable (Employees' satisfaction). Based on the result the researchers concluded that there is no statistical significant impact at $(\alpha \leq 0.05)$ of the ECC (Reliability, Responsiveness and Privacy) on the dependant variable (Employees' satisfaction), but the independent variable (Tangible) has impact on the dependant variable (Employees' satisfaction).

HO (1.1): There is no statistical significance impact of applying ECC system in employees' satisfaction in Jordanian Islamic banks in terms of Responsiveness.

Table 6. Simple regression results for the applying ECC system in employees' satisfaction in Jordanian Islamic banks in terms of responsiveness

\begin{tabular}{cccccccc}
\hline IV & Model & Df & R-Square & Sum of squires & Mean squire & F & Sig. \\
\hline \multirow{2}{*}{ Responsiveness } & Regression & 1 & .013 & .416 & .416 & 1.909 & .169 \\
& Residual & & & 30.956 & .218 & & \\
\hline
\end{tabular}

Note. *Significant level at $(\alpha \leq 0.05)$.

As shown in Table 6 Simple Linear Regression revealed that F value was (1.909) and its probability (.169), so F-test is not statistically significant at $(\alpha \leq 0.05)$. This result also indicates that the dependent variable (Responsiveness) have no impact on the dependent variable (employees' satisfaction in Jordanian Islamic banks). So the null hypothesis (There is no statistical significance impact of applying ECC system in employees' satisfaction in Jordanian Islamic banks in terms of Responsiveness) was proved.

HO (1.2): There is no statistical significance impact of applying ECC system in employees' satisfaction in Jordanian Islamic banks in terms of Reliability.

Table 7. Simple regression results for the impact of applying ECC system in employees' satisfaction in Jordanian Islamic banks in terms of reliability

\begin{tabular}{cccccccc}
\hline IV & Model & df & R-Square & Sum of squires & Mean squire & F & Sig. \\
\hline \multirow{2}{*}{ Reliability } & Regression & 1 & .011 & .355 & .355 & 1.62. & .205 \\
& Residual & & & 31.372 & .218 & & \\
\hline
\end{tabular}

Note. $*$ Significant level at $(\alpha \leq 0.05)$.

As shown in Table 7 Simple Linear Regression revealed that F value was (1.623) and its probability (.205), so F-test is not statistically significant at $(\alpha \leq 0.05)$. This result also indicates that the dependent variable (Reliability) have no impact on the dependent variable (employees' satisfaction in Jordanian Islamic banks). So the null hypothesis (There is no statistical significance impact of applying ECC system in employees' satisfaction in Jordanian Islamic banks in terms of Reliability) was proved. 
HO (1.3): There is no statistical significance impact of applying ECC system in employees' satisfaction in Jordanian Islamic banks in terms of privacy.

Table 8. Simple regression model results of the impact of applying ECC system in employees' satisfaction in Jordanian Islamic banks in terms of privacy

\begin{tabular}{cccccccc}
\hline IV & Model & Df & R-Square & Sum of squires & Mean squire & F & Sig \\
\hline \multirow{2}{*}{ Privacy } & Regression & 1 & .027 & .846 & .846 & 3.935 & $.049 *$ \\
& Residual & & & 30.526 & .215 & & \\
\hline
\end{tabular}

Note. *Significant level at $(\alpha \leq 0.05)$.

As shown in Table 8 Simple Linear Regression revealed that F value was (3.935) and its probability (.049), so F-test is statistically significant at $(\alpha \leq 0.05)$. R Square was (.027) which means that the independent variable (Privacy) predicts $2.7 \%$ of variance in the dependant variable (Employees' satisfaction) and $97.3 \%$ of variance is explained by other factors. So the null hypothesis (There is no statistical significance impact of applying ECC system in employees' satisfaction in Jordanian Islamic banks in terms of privacy) was not proved and this means that there is statistical significance impact of applying ECC system in employees' satisfaction in Jordanian Islamic banks in terms of privacy.

HO (1.4): There is no statistical significance impact of applying ECC system in employees' satisfaction in Jordanian Islamic banks in terms of Tangibility

Table 9. Simple regression model results of the impact of applying ECC system in employees' satisfaction in Jordanian Islamic banks in terms of tangibility

\begin{tabular}{cclccccc}
\hline IV & Model & Df & R-Square & Sum of squires & Mean squire & F & Sig \\
\hline \multirow{2}{*}{ Tangibility } & Regression & 1 & .054 & 1.679 & 1.679 & 8.031 & $.005^{*}$ \\
& Residual & & & 29.693 & .209 & & \\
\hline
\end{tabular}

Note. *Significant level at $(\alpha \leq 0.05)$.

As shown in Table 9 Simple Linear Regression revealed that $\mathrm{F}$ value was (8.031) and its probability (.005), so F-test is statistically significant at $(\alpha \leq 0.05)$. R Square was (.054) which means that the independent variable (Tangibility) predicts $5.4 \%$ of variance in the dependant variable (Employees' satisfaction) and $94.6 \%$ of variance is explained by other factors. So the null hypothesis (There is no statistical significance impact of applying ECC system in employees' satisfaction in Jordanian Islamic banks in terms of tangibility) was not proved and this means that there is statistical significance impact of applying ECC system in employees' satisfaction in Jordanian Islamic banks in terms of tangibility.

HO 2: There are no statistical significant differences at $(\alpha \leq 0.05)$ in the perceptions of employees toward applying ECC attributed to their demographic variables (gender and experience) in Jordanian Islamic banks.

Firstly: Statistical significant differences in the perceptions of employees toward applying ECC attributed to their demographic variable (gender).

Table 10. T-Test results for the perceptions of employees toward applying ECC attributed to their demographic variable (gender)

\begin{tabular}{cccccc}
\hline sex & mean & F & Sig & T & Sig. \\
\hline Male & 4.298 & .119 & .730 & -.302 & .763 \\
Female & 4.314 & & & & \\
\hline
\end{tabular}

Note. *Significant level at $(\alpha \leq 0.05)$.

Table 10for T-test for two independent variables revealed that there is no statistical significant differences at ( $\alpha \leq$ 0.05 ) in the perceptions of employees toward applying ECC attributed to their demographic variable (gender) since the significance value for the $\mathrm{t}(-.302)$ is (.763) which is higher than (0.05). 
Table 11. ANOVA results for the perceptions of employees toward applying ECC attributed to their demographic variable (experience)

\begin{tabular}{ccc}
\cline { 2 - 3 } $\mathrm{Sig}$ & $\mathrm{F}$ & Independent Variables \\
\hline $.035^{*}$ & 2.944 & Experience \\
\hline
\end{tabular}

Note. *Significant level at $(\alpha \leq 0.05)$.

Secondly: Statistical significant differences in the perceptions of employees toward applying ECC attributed to their demographic variable (experience).

Table 11 for ANOVA test revealed that there are statistical significant differences at $(\alpha \leq 0.05)$ in the perceptions of employees toward applying ECC attributed to their demographic variable (experience) $\mathrm{F}=(2.944)$ and its sig (.035). The researcher did Scheffe test for the perceptions of employees toward applying ECC attributed to their demographic variable (experience) and found that no difference in the means for the benefit of any experience items as shown in Table 12.

Table 12. Scheffe test for the perceptions of employees toward applying ECC attributed to their demographic variable (experience)

\begin{tabular}{cccccc}
\hline Ten or more & Sex years to ten & Two years to five & one year or less & mean & Experience \\
\hline .965 & 1.00 & .202 & ---- & 4.238 & one year or less \\
.184 & .072 & --- & .202 & 4.427 & Two years to five \\
.959 & ---- & .072 & 1.00 & 4.247 & Sex years to ten \\
--- & .959 & .184 & .965 & 4.282 & Ten or more \\
\hline
\end{tabular}

Note. $*$ Significant level at $(\alpha \leq 0.05)$.

\section{Discussion, Implications and Recommendations}

In this chapter the researcher tries to answer questions of the study and discuss the results of testing the hypotheses of the study. The contributions of the study and its limitations will be introduced. The researcher also tries to introduce some recommendations and suggest future researches that might be built on the finding of this study.

\subsection{Answering the Study Questions}

In this section the researcher introduced an answering of the study questions.

Answering of the main question: What is the effect of applying electronic clearing in employees' satisfaction in Jordanian Islamic banks? the results of the data analysis of this study revealed that the effect of applying electronic clearing in employees' satisfaction in Jordanian Islamic banks is weak since Multiple Linear Regression revealed that $\mathrm{F}$ has low value which was (2.833) and its probability (.027), R Square was (.075) which means that the whole model predicts $7.5 \%$ of variance in the dependant variable (Employees' satisfaction) and $92.5 \%$ of variance in the dependant variable (Employees' satisfaction) was explained by other factors. It also revealed that $(\mathrm{t})$ values for the independent variables (Reliability, Responsiveness and Privacy) are $(1.042, .281$ and 1.031 respectively) and all of them are not statistically significant at $(\alpha \leq 0.05)$ which means that all these variable don't contribute to the model and that these variables have no effect on the dependant variable (Employees' satisfaction). All of $\beta$ 's values for the independent variables (Reliability, Responsiveness, tangibility and Privacy) are positive which indicates a positive relationship between independent variables (Reliability, Responsiveness, tangibility and Privacy) and the dependant variable (Employees' satisfaction).

Answering of question one: What is the respondents' perceptions level toward the electronic cheque clearing system? 
Table 13. Means and standard deviations of the respondents' perceptions level toward the electronic cheque clearing system

\begin{tabular}{cccccc}
\hline Sort by by mean & Sort by by Importance & St. d & Mean & Dimensions & Items \\
\hline High & 4 & .444 & 4.11 & Reliability & $1-5$ \\
High & 1 & .559 & 4.41 & Responsiveness & $6-11$ \\
High & 2 & .436 & 4.36 & Tangible & $12-15$ \\
High & 3 & .512 & 4.33 & Privacy & $16-20$ \\
High & - & .303 & 4.30 & ECC & $1-20$ \\
\hline
\end{tabular}

To answer this question, the means and the standard deviation of respondents' perceptions level toward the electronic cheque clearing system (ECC) are calculated. The results show that the means of respondents' perceptions level toward the ECC (Reliability, Responsiveness, Tangible and Privacy) are high. The mean was high and it was (4.303) and its standard deviation was (.303). The perceptions toward Responsiveness came first with mean of (4.41) and standard deviation of (.559), then perceptions toward Tangible came second with mean of (4.36) and standard deviation of (.436). After that, the perceptions toward Privacy came thirdly with mean of (4.33) and standard deviation of (.512). The perceptions toward Reliability came fourthly with mean of (4.11) and standard deviation of (.444). None of the previous studies findings met this conclusion.

Answering of question two: To what extent do Islamic banks in the south of the Jordan apply the ECC system? The researcher visited all of the Islamic banks in Jordan to distribute the questionnaire to gather the required data and found that there is a section or department of ECC which means that all of Islamic banks in Jordan apply ECC system.

\section{Discussion of the Findings}

Depending on the results of testing of the hypotheses, the researcher proposed the following discussion:

1-Multiple linear regression results revealed that R Square was (.075) which means that the whole model predicts $7.5 \%$ of variance in the dependant variable (Employees' satisfaction) and $92.5 \%$ of variance in the dependant variable (Employees' satisfaction) was explained by other factors. This result indicates that there is a weak impact of the independent variable the applying ECC system (Reliability, Responsiveness, Tangibility and Privacy) on the dependent variable (Employees' Satisfaction) in Jordanian Islamic banks. Against expectation, the results show that only Tangibility has a positive and significant relationship with "Employees' Satisfaction" $(\beta=0.213, \mathrm{P}<0.05)$. This results indicates that more availability of tangibility in Jordanian Islamic banks, the more of employees' satisfaction. The results also suggest that the relationship between the independent variables (Reliability, Responsiveness, Tangibility and Privacy) and the dependent variable (Employees' Satisfaction) is direct since the sign of the $\beta$ coefficient were positive.

2-As shown in table; Simple Linear Regression revealed that the independent variables (Responsiveness, Reliability and Privacy) have no impact on the dependent variable (Employees' Satisfaction). But independent variable (Tangibility) has impact on the dependent variable (Employees' Satisfaction). The potential explanation of this results are that most of the respondents (employees' satisfaction in Jordanian Islamic banks,) in this study interest only in what makes their work easy to be done and that what tangibility, that related to their work, do and think that the other dimensions (Reliability, Responsiveness and Privacy) may be related to customers' satisfaction more than their satisfaction.

3- t-test revealed that there are no statistical significant differences at $(\alpha \leq 0.05)$ in the perceptions of employees toward applying ECC attributed to their demographic variable (gender), but other Tables for ANOVA test revealed that these differences are found attributed to their experience which means that employees' experience affect their perceptions toward applying ECC in the Islamic banks in Jordan.

\section{Contributions of the Study}

Each study should contribute the literature that related to the study field and to the population of these studies, other else it doesn't worth. So this study introduces the following contributions to the literature that related to the study field and to the population of this study:

- The thesis consists of a literature review of important background knowledge for the applying ECC and employees' satisfaction.

- It draws conclusions and recommendations which may contribute to the future researches. 


\section{Recommendations and Future Researches}

In this section the researcher tries, based on the results of hypotheses testing, to introduce some recommendations that may benefit staff of the Jordanian Banks in general. Also the researchers try to suggest some future researches that may build on this research results.

\subsection{Recommendations of the Study}

The researchers suggested the following recommendations for the benefit of the population of this study in general:

- The head of banks should know what affect and what don't affect their employees' satisfactions affect because employees' satisfaction is a critical factor that may lead to enhance employees' work and this may lead develop workplace.

- Because of this importance employees' satisfaction should be measured continuously.

- Employees' satisfaction in bank sector may affect customers' satisfaction positively or negatively because most of employees in this sector deal with customers face to face. So they should always.

\section{References}

Aarti, C., Seema, C., Bhawna, C., \& Jyoti, C. (2013). Job Satisfaction Among Bank Employees: An Analysis Of The Contributing Variables Towards Job Satisfaction. IJSTR, 2(8).

Alaumayrien, A. M. (2013). The Impact of Desire in Training on the Relationship between Training and Trainee's Performance at the Arab Potash Company. Unpublished thesis, Mutah University, Deanship of Graduate Studies.

Annual Report of Central Bank of Jordan. (2013). Retrieved from http://www.cbj.gov.jo/pages.php?menu_id=12\%26local_type=0\&local_id=0\&local_details=0\&local_details $1=0 \&$ localsite_branchname $=$ CBJ

Aladwani, A. M. (2001). Online banking: A field study of drivers, development challenges, and expectations. International Journal of Information Management, 21(3), 213-225. http://dx.doi.org/10.1016/S0268-4012(01)00011-1

Alter, A. L., \& Oppenheimer, D. M. (2009). Suppressing secrecy through meta cognitive ease. Psychological Science, 20(11), 1414-1420. http://dx.doi.org/10.1111/j.1467-9280.2009.02461.x

Aziri, B. (2011). Job Satisfaction. Management Research and Practice, 3(4), 77-86.

Alabar, T. T., \& Agema, R. J. (2014). Information and Communication Technology and Customer Satisfaction in the Nigerian Banking Industry. Journal of Advanced Management Science, 2(4). http://dx.doi.org/10.12720/joams.2.4.333-338

Bolton, L. (1991). Are you sitting comfortably? Accountancy, 108(1179), 123.

Bowen, D. E., Gilliland, S., \& Folger, R. (1999). HRM and service fairness: How being fair with employees spill over to customers. Organizational Dynamics, 27, 7-23. http://dx.doi.org/10.1016/S0090-2616(99)90018-9

Bowen, D. E., Schneider, B., \& Kim, S. (2000). Shaping service cultures through strategic human resource management. Handbook of Services Marketing (pp. 439-454). Beverly Hills, CA: Sage Publications. http://dx.doi.org/10.4135/9781452231327.n30

Cavoukian, A., \& Dixon, M. (2013). Privacy and Security by Design: An Enterprise Architecture Approach. Information and Privacy Commissioner Ontario, Canada. Retrieved from http://www.ipc.on.ca/site_documents/pbd-privacy-and-security-by design-oracle.pdf

Central Bank of Jordan. (2009). A report on the stability of the financial sector in Jordan. Central Bank of Jordan. Retrieved from CBJ website.

Clacher, I. (2006). Challenges Facing Banking in Emerging Markets. A Case Study on the Tanzanian National Payments Systems. Journal of Financial Regulation and Compliance, 14, 112-118. http://dx.doi.org/10.1108/13581980610644798

Cozby, P. C. (1973). Self-disclosure: A literature review. Psychological Bulletin, 79(2), 73-91. http://dx.doi.org/10.1037/h0033950

Chigot, P. (2005). Effects of sound in offices: Subjective experience vs. objective assessment. Facilities, 23(3/4),152-63. http://dx.doi.org/10.1108/02632770510578520 
D'Astous, A., Colbert, F., \& Montpetit, D. (2005). Music piracy on the web-how e_ective are anti-piracy arguments? Journal of Consumer Policy, 28, 289-310. http://dx.doi.org/10.1007/s10603-005-8489-5

Duncan, E. M., Forbes-McKay, K., \& Henderson, S. E. (2012). Alcohol use during pregnancy: An application of the theory of planned behavior. Journal of Applied Social Psychology, 42(8), 1887-1903. http://dx.doi.org/10.1111/j.1559-1816.2012.00923.x

Edwards, L., \& Torcellini, P. (2002). A literature review of the effects of natural light on building occupants. National Renewable Energy Laboratory: Colorado. http://dx.doi.org/10.2172/15000841

Hrishikesh, S., Akshay, G., Harsha, S., \& Vivek, I. (2014). Cheque Deposition System Using Image Processing \& TCP-IP Protocol International. Journal of Advanced Research in Electrical, Electronics and Instrumentation Engineering, 3(3).

Haitham, H., \& Shibly, A. (2011). An Extended Tam Model to Evaluate User's Acceptance of Electronic Cheque Clearing Systems at Jordanian Commercial Banks. Australian Journal of Basic and Applied Sciences, $147-156$.

Henderson, S., \& Gilding, M. (2004). I've never clicked this much with anyone in my life: Trust and hyperpersonal communication in online friendship. New Media and Society, 6(4), 487-506. http://dx.doi.org/10.1177/146144804044331

Howcroft, B., Hamilton, R., \& Hewer, P. (2001). Consumer attitude and the usage and adoption of home-based banking in the United Kingdom. The International Journal of Bank Marketing, 20(3), 111-121. http://dx.doi.org/10.1108/02652320210424205

Hua, G. Y. (2009). An Experimental Investigation of Online Banking Adoption in China. Journal of Internet Banking and Commerce, 14(1).

Olanipekun, Wahid, D., Brimah, A. N., \& Ajagbe, S. T. (2013). Role of Electronic Banking in Enhancing Human Resource Performance and Customer Satisfaction: Evidence from Guaranty Trust.

Qatawneh, A. (2012). The effect of Electronic commerce on the effectiveness of accounting information systems. International Business Research, 5(5). http://dx.doi.org/10.5539/ibr.v5n5p158

Sowmya, K. R., \& Panchanatham, N. (2011). Factors influencing job satisfaction of banking sector employees in Chennai, India. Journal of Law and Conflict Resolution, 3(5), 76-79.

Rotter, J. B. (1980). Interpersonal trust, trustworthiness, and gullibility. American Psychologist, 35(1), 1-7. http://dx.doi.org/10.1037/0003-066X.35.1.1

Karimi-Shahanjarini, A., Rashidian, A., Majdzadeh, R., Omidvar, N., Tabatabai, M., \& Shojaeezadeh, D. (2012). Parental control and junk-food consumption: A mediating and moderating effect analysis. Journal of Applied Social Psychology, 42(5), 1241-1265. http://dx.doi.org/10.1111/j.1559-1816.2011.00885.x

Knowles, S. R., Hyde, M. K., \& White, K. M. (2012). Predictors of young people's charitable intentions to donate money: An extended theory of planned behavior perspective. Journal of Applied Social Psychology 42(9), 2096-2110. http://dx.doi.org/10.1111/j.1559-1816.2012.00932.x

Lee, M. (2009). Predicting and explaining the adoption of online trading: An empirical study in Taiwan. Decision Support Systems, 47, 133-142. http://dx.doi.org/10.1016/j.dss.2009.02.003

Louis, W. R., Davies, S., Terry, D. J., \& Smith, J. R. (2007). Pizza and pop and the student identity: The role of referent group norms in healthy and unhealthy eating. Journal of Social Psychology, 147, 57-74. http://dx.doi.org/10.3200/SOCP.147.1.57-74

Lymperopoulos, C., \& Chaniotakis, E. (2004). Branch employees' perceptions towards implications of e-banking in Greece. International Journal of Retail \& Distribution Management, 32(6), 302-311. http://dx.doi.org/10.1108/09590550410538006

Paine, C., Reips, U. D., Steiger, S., Joinson, A., \& Buchanan, T. (2006). Internet users' perceptions of 'privacy concerns' and 'privacy actions'. International journal of Human-Computer Studies, 65, 526-536. http://dx.doi.org/10.1016/j.ijhcs.2006.12.001

Pasupathinathan, V., Pieprzyk, J., \& Wang, H. (2005). Privacy Enhanced Electronic Cheque System. Proceedings of the Seventh IEEE International Conference on E-Commerce Technology. http://dx.doi.org/10.1109/ICECT.2005.68

Jresat, N. F. (2007). Economic Impact of Applying Electronic Cheque Clearing Solution: A Case Study-State of 
Qatar (2001-2005). Unpublished Master Thesis, University of Jordan, Amman, Jordan.

Jeremy, D. E. M. (2005). Traditional-Cheque Processing. Retrieved from http://www.docstoc.com/docs/161633709/Traditional-Cheque Processing.30/6/2014

Sekaran, U. (2003). Research Methods for Business: Skill Buildings Approach. New York: John Wiley and Sons.

Somkid, Y. (2012). The Efficiency of the ICAS System. International Monthly Refereed Journal of Research In Management \& Technology, 1 .

Maxwell, A. (2011). Exploring the Effects of Information Communication Technology (ICT) on Custmer Satisfaction. The Case of Barclays Bank of Ghana LTD. Retrieved from http://dspace.knust.edu.gh/jspui/bitstream/123456789/4434/1/Maxwell\%20Agyapong.pdf

Mrs, G. S. (2011). Customer's perception of service quality of State Bank of India-A Factor Analysis. IJMBS l(3).

Moutinho, L., Davies, F., Deng, S., Miguel, P. S., \& Alcaniz, J. E. (1997). The future role of bank branches and their managers: Comparing managerial perceptions in Canada and Spain. International Journal of Bank Marketing, 15(3), 99-105. http://dx.doi.org/10.1108/02652329710166019

Nancy, B., Lockett, A., Winklhofer, H., \& Christine, E. (2001). The adoption of Internet financial services: A qualitative study. International Journal of Retail \& Distribution Management, 29(8), 390-398. http://dx.doi.org/10.1108/09590550110397033

Nolan, J. P., Schultz, P. W., Cialdini, R. B., Goldstein, N. J., \& Griskevicius, V. (2008). Normative social influence is underdetected. Personality and Social Psychology Bulletin, 34, 913-923. http://dx.doi.org/10.1177/0146167208316691

Venkatesh, V., \& Davis, F. D. (2000). A Theoretical Extension of the Technology Acceptance Model: Four Longitudinal Field Studies. Management Science, 46(2), 186-204. http://dx.doi.org/10.1287/mnsc.46.2.186.11926

Wang, Y., Lin, H., \& Tang, T. (2003). Determinants of user acceptance of internet banking: An empirical study. International Journal of Service Industry Management, 14(5), 501-519. http://dx.doi.org/10.1108/09564230310500192

Welch, B. (1999). Electronic Banking and Treasury Security-A Guide for Corporate and Financial Manager. Retrieved from http://dspace.knust.edu.gh/jspui/bitstream/123456789/4434/1/Maxwell\%20Agyapong.pdf

Yahya, A. A., Hani, H. A., \& Haitham, H. A. (2011). Exploring Electronic Cheque Clearing Systems Acceptance by Jordanian Commercial Banks: A Theoretical Integration of Technology Acceptance Model, User Satisfaction and Delone and Mclean Model. Jordan Journal of Business Administration, 7(3).

Yasuharu, U. (2003). The Effects of Information System Investment in Banking Industry. Retrieved from http://dspace.knust.edu.gh/jspui/bitstream/123456789/4434/1/Maxwell\%20Agyapong.pdf

Youn, S., \& Hall, K. (2008). Gender and online privacy among teens: Risk perception, privacy concerns, and $\begin{array}{lllll}\text { protection } & \text { behaviors. } & \text { Cyberpsychology } \& \text { Behavior, } & \text { 11(6), }\end{array}$ http://dx.doi.org/10.1089/cpb.2007.0240

Yao, M. Z., \& Linz, D. G. (2008). Predicting self-protections of online privacy. Cyberpsychology \& Behavior, 11(5), 615- 616. http://dx.doi.org/10.1089/cpb.2007.0208

Yousafzai, S. Y., Foxall, G. R., \& Pallister, J. G. (2010). Explaining internet banking behavior: Theory of reasoned action, theory of planned behavior, or technology acceptance model? Journal of Applied Social Psychology, 40(5), 1172-1202. http://dx.doi.org/10.1111/j.1559-1816.2010.00615.x

\section{Copyrights}

Copyright for this article is retained by the author(s), with first publication rights granted to the journal.

This is an open-access article distributed under the terms and conditions of the Creative Commons Attribution license (http://creativecommons.org/licenses/by/3.0/). 